\title{
Radiochemical Characterization of Phosphogypsum for Engineering Use
}

\author{
Hanan Tayibi ${ }^{1}$, Catalina Gascó ${ }^{2}$, Nuria Navarro ${ }^{2}$, Aurora López-Delgado ${ }^{1}$, Mohamed Choura ${ }^{3}$, \\ Francisco J. Alguacil ${ }^{1}$, Félix A. López ${ }^{1 *}$
}

${ }^{1}$ National Centre for Metallurgical Research (CENIM), CSIC. Avda. Gregorio del Amo, Madrid, Spain; ${ }^{2}$ Centro de Investigaciones Energéticas, Medioambientales y Tecnológicas (CIEMAT). Avda. Complutense, Madrid, Spain; ${ }^{3}$ National Engineering School, Sfax University, Sfax, Tunisia.

Email: flopez@cenim.csic.es

Received November $22^{\text {nd }}, 2010$; revised January $17^{\text {th }}, 2011$; accepted March $7^{\text {th }}, 2011$.

\begin{abstract}
The new phosphogypsum (PG) waste management policy allowed to reduce the negative environmental impact of this residue by finding better alternatives uses with an extremely limited radiological impact. Building material could be one of these alternatives that could lead to the production of final products with good mechanical properties and very limited radionuclides content. The optimization of the radioactive levels in the building materials when PG is used for its production requires the previous knowledge of the content of naturally occurring radionuclides in the PG waste. This article aims the radioactive characterization of two different PG sources (from Spain (Fertiberia S.A., Huelva) and Tunisia (Sfax), before being incorporated in building materials. For this purpose, the natural selected radionuclides content belonging to uranium and thorium decay series and ${ }^{40} \mathrm{~K}$ was determined, by means of two different methods: i) gamma spectrometry with high-purity germanium detectors and ii) laser-induced kinetic phosphorimetry (KPA-11 Chemcheck Instruments Inc., Richland, WA). Also, the semiquantitative chemical composition, the mineralogical study and the morphological aspect of the PG samples were analysed. The results obtained from both techniques show that ${ }^{226} \mathrm{Ra}$ and ${ }^{210} \mathrm{Po}$ are the main source of the radioactivity in both studied $P G$ samples. However, PG samples from Tunisia present low natural radionuclide levels $\left(30.7 \mathrm{~Bq} \cdot \mathrm{kg}^{-1}\right.$ average value for ${ }^{238} \mathrm{U}, 188 \mathrm{~Bq} \cdot \mathrm{kg}^{-1}\left({ }^{226} \mathrm{Ra}\right), 163$ $\mathrm{Bq} \cdot \mathrm{kg}^{-1}\left({ }^{210} \mathrm{~Pb}\right), 12.4 \mathrm{~Bq} \cdot \mathrm{kg}^{-1}\left({ }^{232} \mathrm{Th}\right)$ compared to the level of natural radionuclides in PG samples from Huelva (102 $\mathrm{Bq} \cdot \mathrm{kg}^{-1}$ average value for ${ }^{238} \mathrm{U}, 520 \mathrm{~Bq} \cdot \mathrm{kg}^{-1}\left({ }^{226} \mathrm{Ra}\right), 881 \mathrm{~Bq} \cdot \mathrm{kg}^{-1}\left({ }^{210} \mathrm{~Pb}\right)$ and $8 \mathrm{~Bq} \cdot \mathrm{kg}^{-1}\left({ }^{232} \mathrm{Th}\right)$. Both PG fulfil European Commission Recommendation (ECR) for the maximum activity concentrations of naturally-occurring radionuclides for industrial by product used in building materials in the European Union.
\end{abstract}

Keywords: Phosphogypsum, Radionuclides Analysis, Phosphate Industry, Gamma Spectrometry, TENORM

\section{Introduction}

Phosphogypsum (PG) is an industrial residue from processing phosphate rock using the "wet acid" process to produce the phosphoric acid $\left(\mathrm{H}_{3} \mathrm{PO}_{4}\right)$ in fertilizer plants (Equation (1)), which currently accounts for over $90 \%$ of phosphoric acid production.

$$
\begin{aligned}
\mathrm{Ca}_{5} \mathrm{~F}\left(\mathrm{PO}_{4}\right)_{3}+5 \mathrm{H}_{2} \mathrm{SO}_{4} & +10 \mathrm{H}_{2} \mathrm{O} \\
& \rightarrow 3 \mathrm{H}_{3} \mathrm{PO}_{4}+5 \mathrm{CaSO}_{4} \cdot 2 \mathrm{H}_{2} \mathrm{O}+\mathrm{HF}
\end{aligned}
$$

This process is economic however it results in the generation of a large amount of PG (for every ton of phosphoric acid produced, about 5 tons of $\mathrm{PG}$ are yielded). The worldwide generation is estimated to be around 100 - 280 Mt per year [1,2]. PG consists principally of calcium sulphate $\left(\mathrm{CaSO}_{4} \cdot 2 \mathrm{H}_{2} \mathrm{O}\right)$ but also contains a high level of impurities such as phosphates, fluorides and sulphates, naturally occurring radionuclides, heavy metals, and other trace elements.

Nowadays, PG represents one of the most serious problems faced by the phosphate industry, since commercial uses, in manufacturing gypsum board and Portland cement and in agricultural fertilisers or soil stabilisation amendments, consume less than $15 \%$ of the worldwide generation of PG. The remaining $85 \%$ is disposed of without any treatment and usually dumped in large stockpiles exposed to weathering processes, occupying considerable land areas and causing serious environmental contamination of soils, water and the atmosphere, particularly in coastal regions [3]. The main prob- 
lem associated with the storage of PG is considered to be the relatively high levels of natural uranium-series radionuclides, naturally present in the phosphate rock and which provoke a negative environmental impact and many restrictions on the use of this residue. Depending on the quality of the phosphate rock source, PG can contain as much as 60 times the levels normally found prior to processing. Previous study performed by Bolivar [4] showed that about $80 \%$ of the ${ }^{226} \mathrm{Ra}, 90 \%$ of the ${ }^{210} \mathrm{Po}$ and $20 \%$ of the ${ }^{238} \mathrm{U}$ and ${ }^{234} \mathrm{U}$ originally present in the phosphate rock remain in PG. Furthermore, the most important source of $\mathrm{PG}$ radioactivity is reported to be ${ }^{226} \mathrm{Ra}$ [5]. ${ }^{226} \mathrm{Ra}$ produces radon gas $\left({ }^{222} \mathrm{Rn}\right)$, which has a short half-life of 3.8 days, an intense radiation capacity, and causes significant damage to internal organs [6]. Thus the potential problem of PG piles is the emanation of ${ }^{222} \mathrm{Rn}$ from the alpha-decay of ${ }^{226} \mathrm{Ra}$, a radionuclide classified by the USEPA as a Group human carcinogen, whose common presence in PG led to the regulation of PG disposal under the National Emission Standards for Hazardous Air Pollutants (NESHAP) and the National Emission Standards for Radon Emission from PG Stacks [7]. The United States Environmental Protection Agency (USEPA) classified PG as a "Technologically Enhanced Naturally Occurring Radioactive Material" (TENORM) [6] and PG exceeding $370 \mathrm{~Bq} / \mathrm{kg}$ of radioactivity has been banned from all uses by the EPA since 1992. The maximum regulatory limit of ${ }^{222} \mathrm{Rn}$ exhalation (the flux density of ${ }^{222} \mathrm{Rn}$ gas entering the atmosphere from the surface of a ${ }^{226} \mathrm{Ra}$-bearing material) established by the EPA [8] is $0.74 \mathrm{~Bq} / \mathrm{m}^{2} / \mathrm{s}$.

In Huelva (Spain), PG stacks located on salt marshes contain about $100 \mathrm{Mt}$ of PG (area of approx. 1200 ha with average height of $5 \mathrm{~m}$ ) and are generally not completely watertight or even covered with any inert material, leading to a local gamma radiation level between 5 and 38 times the normal rate $\left(0.74 \mathrm{~Bq} / \mathrm{m}^{2} / \mathrm{s}\right)$ [9]. The same situation is observed in Sfax (Tunisia), where PG is accumulated in two enormous warehouses situated at the coastal strip of the urban area, the first one is $12 \mathrm{~m} \mathrm{high}$ and covers an area of $40 \mathrm{ha}$, and the other one, $30 \mathrm{~m}$ high, covers an area of 60 ha.

The present study was conducted to determine the natural selected radionuclides content belonging to uranium and thorium decay series and ${ }^{40} \mathrm{~K}$ in the two different $\mathrm{PG}$ sources mentioned above, using two different methods.

\section{Material and Methods}

The PG samples used in this study came from a fertiliser factory in Sfax city, Tunisia and from Fertiberia S.A., Huelva, Spain.

The semiquantitative chemical composition of the PG samples was identified by an X-ray fluorescence analyser (Philips model PW-1404 sequential wavelength dispersion unit). Mineral species were determined by X-ray diffraction (Siemens model D5000, with a $\mathrm{Cu}$ tube and $\mathrm{LiF}$ monochromator). The morphological aspect of the PG was analysed using scanning electron microscopy (SEM) (Joel model JXA-840) with energy dispersive spectroscopy (EDS). Natural selected radionuclides belonging to uranium and thorium decay series and ${ }^{40} \mathrm{~K}$ present in PG samples have been quantified as shown in the Figure 1.

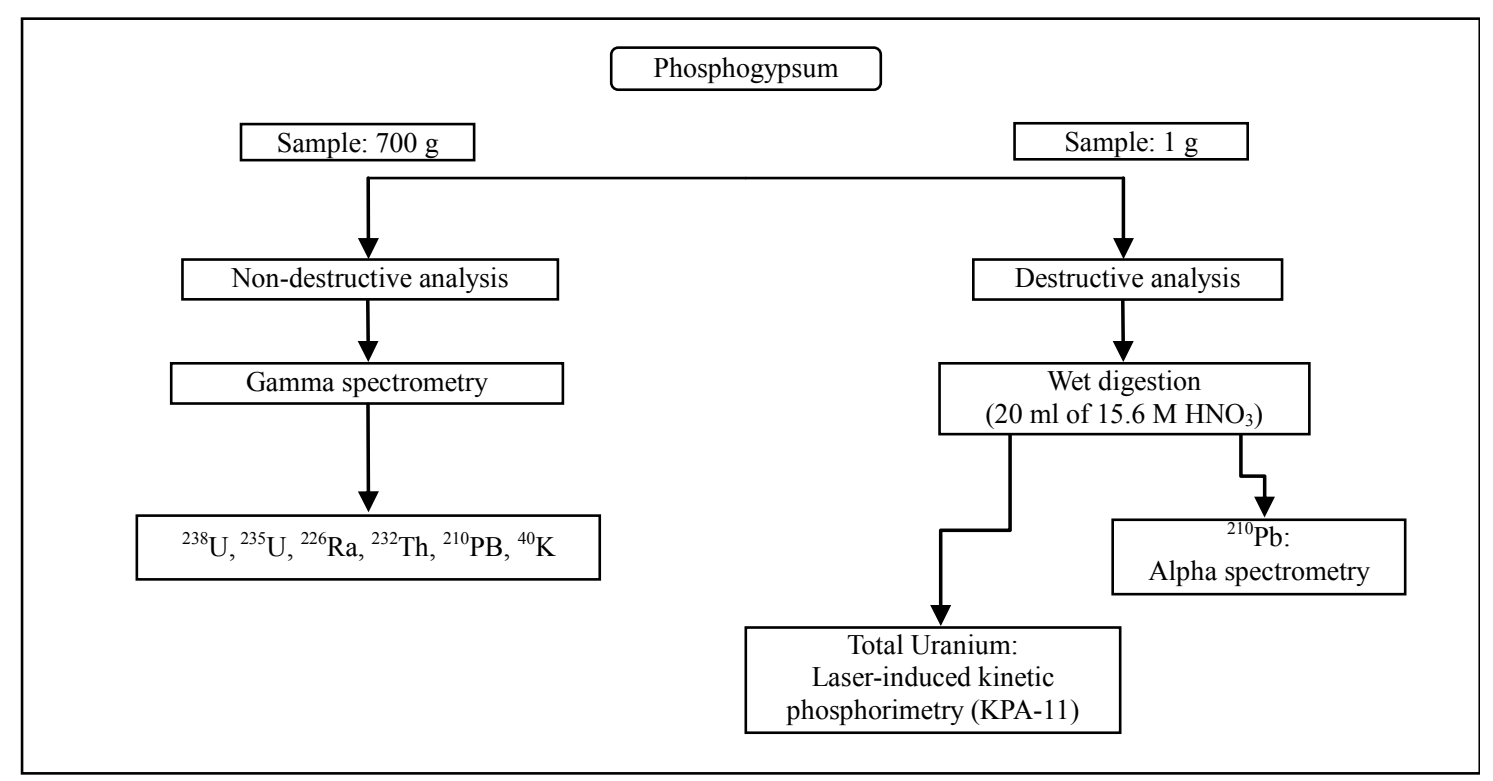

Figure 1. Scheme of radionuclides quantification procedure. 
Uranium: the uranium content in the samples was determined using two different methods: 1) Direct measurements by gamma spectrometry with high-purity germanium detectors and 2) Laser-induced kinetic phosphorimetry. The direct measurements were carried out on 700-g aliquots of the samples packed in standard marinelli beakers. The ${ }^{238} \mathrm{U}$ activity concentration was determined through the photopeaks of its immediate decay product, ${ }^{234} \mathrm{Th}$ (63 and $92.5 \mathrm{keV}$ ), whereas ${ }^{235} \mathrm{U}$ was measured directly from its 143.8 and $163.4 \mathrm{keV}$ gammaray peaks. Concerning Laser-induced kinetic phosphorimetry technique, $1 \mathrm{~g}$ of the sample was completely digested in $15.6 \mathrm{~mol} \cdot \mathrm{l}^{-1} \mathrm{HNO}_{3}$ and the measurements were performed using a kinetic phosphorescence analyzer (KPA-11) (Chemcheck Instruments Inc., Richland, WA) [10]. In order to compare the results obtained by both techniques, the total uranium concentration obtained by
Laser-induced kinetic phosphorimetry, expressed in $\mu \mathrm{g} \cdot \mathrm{g}^{-1}$, were then converted to the activity concentration of each uranium isotope. Theoretical values of the isotopic composition of natural uranium $\left(99.3 \%{ }^{238} \mathrm{U}, 0.72 \%\right.$ ${ }^{235} \mathrm{U}$, and $5.5 \cdot 10^{-3} \%{ }^{234} \mathrm{U}$ ) and the specific activities of these isotopes in natural uranium $\left(\mathrm{Bq} \cdot \mathrm{g}^{-1}\right)$ were used for this purpose [11].

Polonium: the polonium activity concentration in the both samples was determined by alpha spectrometry, following the ${ }^{210} \mathrm{Po}$ separation procedure described in the Figure 2 [12]. An aliquot of $1 \mathrm{~g}$ was digested in a hot plate at a controlled temperature $\left(<90^{\circ} \mathrm{C}\right)$, using $8 \mathrm{~mol} \cdot \cdot^{-1} \mathrm{HNO}_{3}$. Polonium-209 standard dissolution was added to the dissolved samples as a tracer to estimate the recovery of the whole process. The polonium isotopes were self- deposited on silver disks following Flynn's method [13].

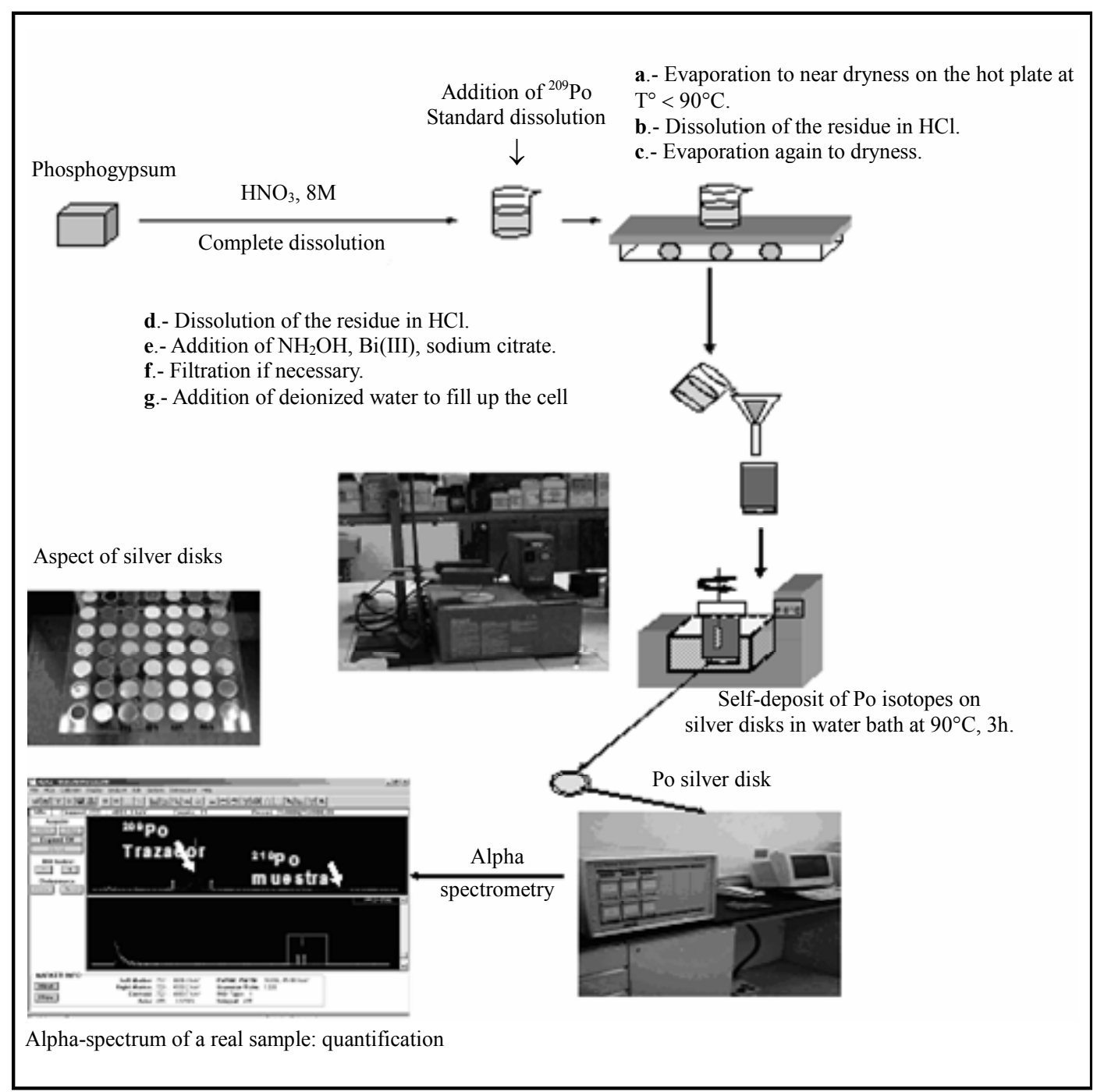

Figure 2. Scheme of ${ }^{210} \mathrm{Po}$ separation procedure. 
${ }^{226} \mathrm{Ra},{ }^{232} \mathrm{Th},{ }^{210} \mathrm{~Pb}$ and ${ }^{40} \mathrm{~K}$ : the concentrations of these radionuclides were quantified by gamma spectrometry analysis using an HPGe detector. The detector was shielded from external radiation by an iron wall $(15 \mathrm{~cm}$ thickness). The emission gamma spectrum was analyzed using Genie-2000 application software. To ensure radioactive equilibrium between ${ }^{226} \mathrm{Ra}$ and its short lived decay products, the samples (700 $\mathrm{g}$ aliquot) were packed in standard marinelli beakers, hermetically sealed and stored for about four weeks prior to counting. The concentration of ${ }^{226} \mathrm{Ra}$ and ${ }^{232} \mathrm{Th}$ was estimated from their daughters gamma-ray photopeaks, ${ }^{214} \mathrm{Bi}(609 \mathrm{keV})$ and ${ }^{228} \mathrm{Ac}(911.2 \mathrm{keV}, 969.0 \mathrm{keV})$ respectively. ${ }^{210} \mathrm{~Pb}$ and ${ }^{40} \mathrm{~K}$ were measured directly from their gamma-ray emissions at $46.5 \mathrm{keV}$ and $1460.8 \mathrm{keV}$ respectively. The minimum detectable activity limit (DL) was also calculated.

\section{Results and Discussion}

\subsection{Phosphogypsum Characterization}

The chemical composition of both type of PG sample is summarised in Table 1. The data shows that sulphate (expressed as $\mathrm{SO}_{3}$ ), $\mathrm{CaO}, \mathrm{SiO}_{2}$ and $\mathrm{P}_{2} \mathrm{O}_{5}$ are the major elements $(50.7,41.24,1.38$ and $1.2 \%$, respectively) for Tunisian PG, and 52.6, 42.82, 2.72 and 0.7 , respectively for Spanish PG.

The Figure 3 reports the powder X-ray diffraction pattern of PG samples. As shown, Spanish PG presents two maximum intensity diffraction peaks corresponding to gypsum $\left(\mathrm{CaSO}_{4} \cdot 2 \mathrm{H}_{2} \mathrm{O}\right)$ (JCPDS 33-0311) and bassanite $\left(\mathrm{CaSO}_{4} \cdot 1 / 2 \mathrm{H}_{2} \mathrm{O}\right)$, while the main diffraction peaks of the Tunisian PG corresponds to gypsum $\left(\mathrm{CaSO}_{4} \cdot 2 \mathrm{H}_{2} \mathrm{O}\right)$.

The morphological study of PG sample using SEM, illustrated in Figure 4, shows two different sections of the sample. The micrographs reveal a homogeneous and prismatic PG piling arrangement and a well-defined crystalline structure with a majority of orthorhombic shaped crystals [14]. Similar results can be observed in the study performed by Miloš and Dragan [15], in which they reported that the marked crystal structure of PG indicates that PG presents a more complex composition than natural gypsum (characterized by a poorly expressed crystalline structure), which may eventually influence its chemical behaviour.

\subsection{Natural Radionuclide Concentrations}

The results of the natural radioactivity concentration analyses of each one of the PG samples by the two techniques employed for this purpose (gamma spectrometry and laser-induced kinetic phosphorimetry) are listed in Tables 2 and $\mathbf{3}$. The average activity concentration of ${ }^{238} \mathrm{U},{ }^{226} \mathrm{Ra},{ }^{210} \mathrm{Po},{ }^{232} \mathrm{Th}$ and ${ }^{40} \mathrm{~K}$ in Tunisian PG samples are $30.7,188,194,12.4$ and $13 \mathrm{~Bq} \cdot \mathrm{kg}^{-1}$, respectively, while in Spanish PG samples are 102, 520, 820, 8 and 39 $\mathrm{Bq} \cdot \mathrm{kg}^{-1}$, respectively. We can deduce that ${ }^{226} \mathrm{Ra}$ and ${ }^{210} \mathrm{Po}$ are the main source of the radioactivity in both $\mathrm{PG}$

Table 1. The major element composition (wt\%) of PG samples.

\begin{tabular}{|c|c|c|c|c|c|c|c|c|c|}
\hline Element (Wt\%) & $\mathrm{CaO}$ & $\mathrm{SiO}_{2}$ & $\mathbf{A l}_{2} \mathbf{O}_{3}$ & $\mathrm{Fe}_{2} \mathrm{O}_{3}$ & MgO & $\mathrm{SO}_{3}$ & $\mathrm{Na}_{2} \mathrm{O}$ & $\mathbf{P}_{2} \mathbf{O}_{5}$ & $\mathbf{F}^{-}$ \\
\hline PG (Tunisia) & 41.24 & 1.38 & 0.11 & 0.09 & 0.02 & 50.7 & 0.59 & 1.2 & 4.9 \\
\hline PG (Spain) & 42.82 & 2.72 & 0.40 & 0.22 & 0.07 & 52.6 & 0.24 & 0.7 & - \\
\hline
\end{tabular}

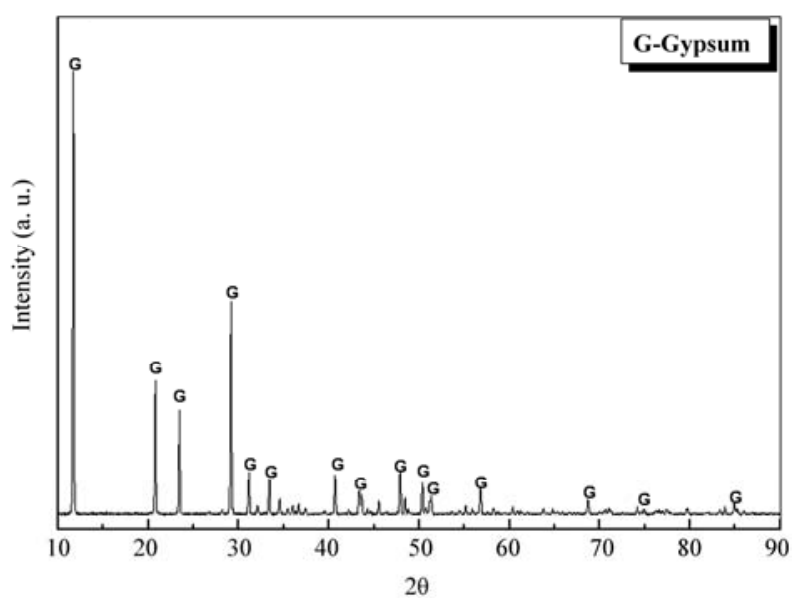

(a)

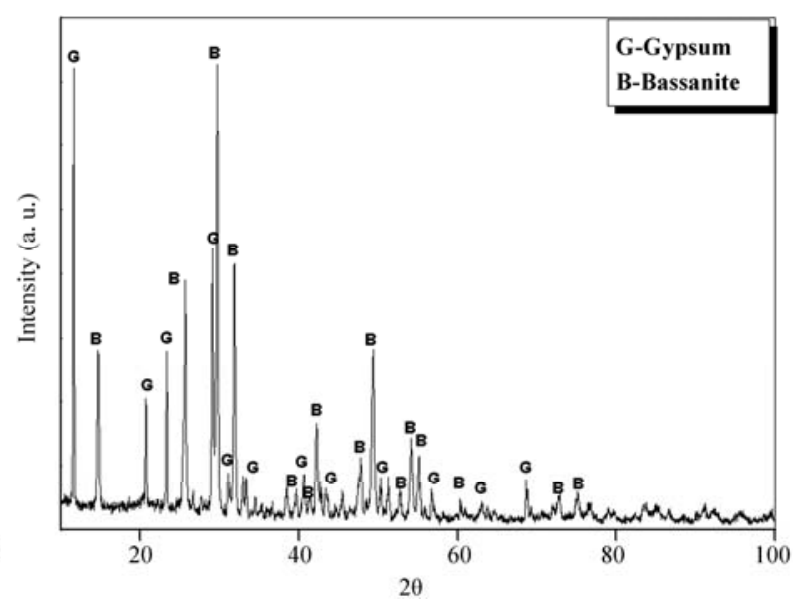

(b)

Figure 3. X-ray pattern of phosphogypsum: (a) from Tunisia and (b) from Spain. Intensities in arbitrary units (a. u.). 

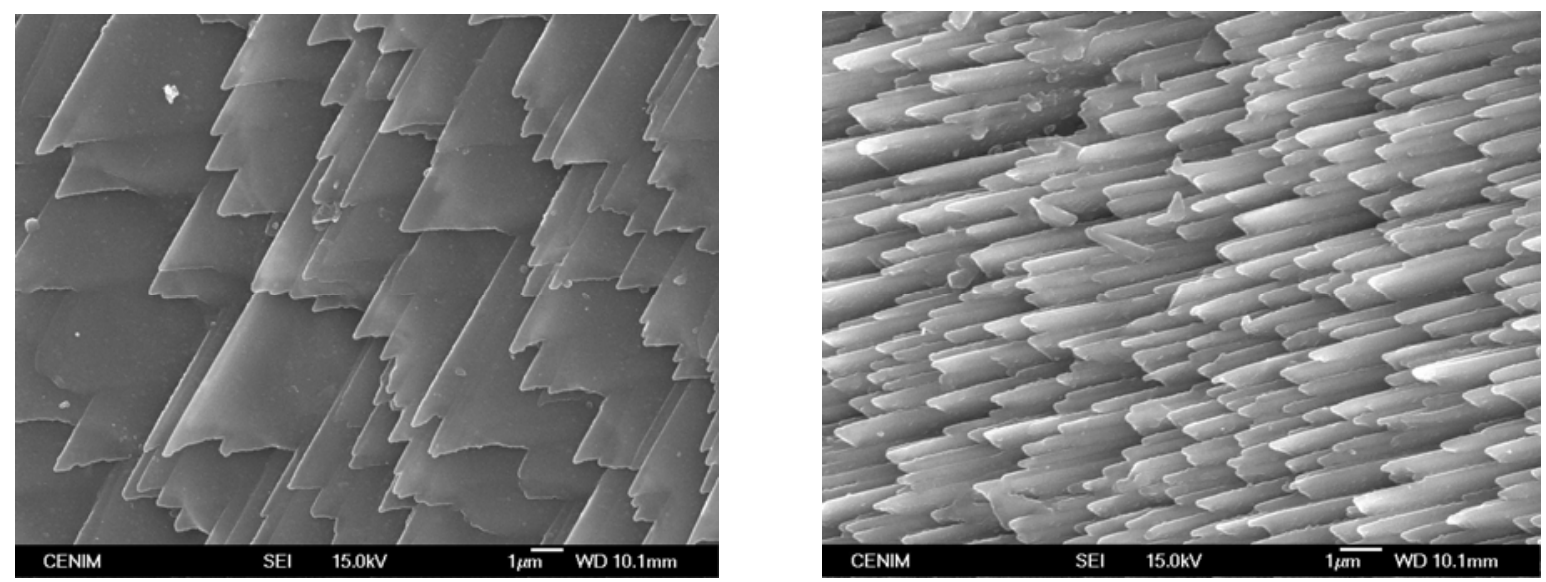

Figure 4. SEM micrographs of two different sections of a PG sample (15 keV).

Table 2. Uranium activity ratio in PG from Spain and Tunisia, expressed in $\mathrm{Bq}^{\circ} \cdot \mathrm{kg}^{-1}( \pm 2 \mathrm{~s})$, by means of phosphorimetry and gamma spectrometry techniques.

\begin{tabular}{|c|c|c|c|c|c|}
\hline \multirow{2}{*}{ Sample } & \multicolumn{3}{|c|}{ U (Phosphorimetry) } & \multicolumn{2}{|c|}{ U (Gamma spectrometry) (DL) } \\
\hline & ${ }^{238} \mathbf{U}$ & ${ }^{234} \mathbf{U}$ & ${ }^{235} \mathbf{U}$ & ${ }^{238} \mathrm{U}\left({ }^{234} \mathrm{Th}\right)$ & ${ }^{235} \mathbf{U}$ \\
\hline PG (Tunisia) & 30.7 & 31.6 & 1.4 & $27 \pm 4.9(40)^{*}$ & $<6.5^{*}$ \\
\hline PG (Spain) & $102 \pm 1$ & $105 \pm 5$ & $4.7 \pm 0.2$ & $81 \pm 28$ & $8 \pm 3(20) *$ \\
\hline
\end{tabular}

${ }^{*}$ DL. Detection Limit

Table 3. Natural radionuclide activity ratio of the 238 Uranium-series (226Ra, 210Pb and $210 \mathrm{Po}$ in this case in radioactive equilibrium), 232 Th and $40 \mathrm{~K}$ expressed in $\mathrm{Bq}^{\circ} \mathrm{kg}^{-1}$ ( $\left.\pm 2 \mathrm{~s}\right)$ in PG from Spain and Tunisia.

\begin{tabular}{cccccc}
\hline Sample & ${ }^{226} \mathbf{R a}\left({ }^{214} \mathbf{B i}\right)$ & ${ }^{210} \mathbf{P b}$ & ${ }^{210} \mathbf{P o}$ & ${ }^{40} \mathbf{K}$ & ${ }^{{ }^{232} \mathbf{T h}\left({ }^{228} \mathbf{A c}\right)}$ \\
\hline PG (Tunisia) & $188 \pm 9.5$ & $163 \pm 81$ & $194 \pm 78$ & $<13.5$ & $12.4 \pm 1.4$ \\
PG (Spain) & $520 \pm 23$ & $881 \pm 58$ & $820 \pm 43$ & $<(39) *$ & $8 \pm 2$ \\
\hline
\end{tabular}

${ }^{*}$ DL. Detection Limit

samples. The results obtained were compared to those reported in other world regions (Table 4) $[5,9,16,17]$. It is found that a special attention is drawn to the low natural radionuclide levels present in the PG samples from Tunisia (30.7 for ${ }^{238} \mathrm{U}, 188\left({ }^{226} \mathrm{Ra}\right), 194\left({ }^{210} \mathrm{Po}\right), 12.4$ $\left({ }^{232} \mathrm{Th}\right)$ and $\left.13 \mathrm{~Bq} \cdot \mathrm{kg}^{-1}\left({ }^{40} \mathrm{~K}\right)\right)$. Furthermore, these values are lower than those of the average worldwide activity concentration of ${ }^{238} \mathrm{U},{ }^{232} \mathrm{Th}$, and ${ }^{40} \mathrm{~K}(50,50$ and 500 $\mathrm{Bq} \cdot \mathrm{kg}^{-1}$, respectively) [18]. This different content may be attributed to the nature of the phosphate rock, the depth of sampling [19] and differences in the industrial process applied to obtain phosphoric acid. Natural radioactivity in the different phases of the production system has recently been analysed by Bolivar et al. [20] showing that $\mathrm{Pb}, \mathrm{Ra}$ and to a certain extent $\mathrm{Th}$ isotopes are exclusively supplied by the phosphate rock and remain associated to the PG particles, while uranium decreases according to the number of washings of the PG.
The data showed that the both studied PG samples (Tunisian and Spanish) fulfil European Commission Recommendation for the maximum activity concentrations of naturally-occurring radionuclides in common buildings materials and industrial by-products used for building materials in the EU [21]. This finding could make possible the use of the studied PG as building material.

Concerning the measurement techniques used in this study, it found that the use of gamma spectrometry for uranium determination allows the analysis of a more representative aliquot of the whole sample than in the case of the KPA technique. KPA has a lower detection limit (sensitivity) and better uncertainty $(6 \%)$, but due to the limitations of wet digestion until total dissolution and chemical interferences, only $1 \mathrm{~g}$ can be analysed. Nevertheless, the results obtained from both techniques are in good agreement. 
Table 4. Activity concentrations of different types of phosphogypsum samples analyzed, in $\mathrm{Bq}_{\mathrm{kg}}{ }^{-1}[5,9,16,17]$.

\begin{tabular}{cccccc}
\hline Origen & ${ }^{238} \mathbf{U}$ & ${ }^{226} \mathbf{R a}$ & ${ }^{210} \mathbf{P b}$ & ${ }^{{ }^{210} \mathbf{P o}}$ & ${ }^{\mathbf{2 3 0}} \mathbf{T h}$ \\
\hline Spain [9] & 220 & 670 & 520 & - & 8.2 \\
China [16] & $15 \mathrm{~d}$ & 85 & 82 & 82 & - \\
Indonesia [16] & 43 & 473 & 480 & 450 & - \\
India [16] & 60 & 510 & 490 & 420 & - \\
Egypt [17] & 140 & 459 & 323 & - & 8.3 \\
Florida [5] & 130 & 1140 & 1370 & 1030 & 113 \\
Australia [5] & 10 & 500 & - & - & - \\
Sweden [5] & 390 & 15 & - & - & - \\
\hline
\end{tabular}

\section{Conclusions}

The sensitivity of the analytical methods is good enough to detect the radionuclides existing in both types of samples.

For uranium quantification, the gamma spectrometry allows the analysis of a more representative aliquot of the whole sample than in the case of the KPA technique. However; KPA has a lower detection limit (sensitivity) and better uncertainty $(6 \%)$.

The PG samples from Tunisia present a low natural radionuclide levels $\left(30.7 \mathrm{~Bq} \cdot \mathrm{kg}^{-1}\right.$ for ${ }^{238} \mathrm{U}, 188 \mathrm{~Bq} \cdot \mathrm{kg}^{-1}$ $\left.\left({ }^{226} \mathrm{Ra}\right), 163 \mathrm{~Bq} \cdot \mathrm{kg}^{-1}\left({ }^{210} \mathrm{~Pb}\right), 12.4 \mathrm{~Bq} \cdot \mathrm{kg}^{-1}\left({ }^{232} \mathrm{Th}\right)\right)$ compared to the level of PG samples from Huelva (102 $\mathrm{Bq} \cdot \mathrm{kg}^{-1}$ for ${ }^{238} \mathrm{U}, 520 \mathrm{~Bq} \cdot \mathrm{kg}^{-1}\left({ }^{226} \mathrm{Ra}\right), 881 \mathrm{~Bq} \cdot \mathrm{kg}^{-1}\left({ }^{210} \mathrm{~Pb}\right)$ and $8 \mathrm{~Bq} \cdot \mathrm{kg}^{-1}\left({ }^{232} \mathrm{Th}\right)$. In both cases, the values are below the maximum activity concentrations limits of naturallyoccurring radionuclides in common buildings materials and industrial by-products used for building materials in the EU, recommended by the European Commission.

\section{Acknowledgements}

The authors are grateful to both, Spanish National R \& D \& I Plan (Project CTQ2008-02012/PPQ) and AECID (Project $\mathrm{N}^{\circ} \mathrm{A} / 5537 / 06$ ) for the financial support of this study. Furthermore, Hanan Tayibi is grateful to CSIC (Spanish Council for Scientific Research) for an I3P contract (I3PDR-6-01).

\section{REFERENCES}

[1] J. Yang, W. Liu, L. Zhang and B. Xiao, "Preparation of Load-Bearing Building Materials from Autoclaved Phosphogypsum," Construction and Building Materials, Vol. 23, 2009, pp. 687-693. doi:10.1016/j.conbuildmat.2008.02.011

[2] A. B. Parreira, A. R. K. Jr. Kobayashi and O. B. Silvestre, "Influence of Portland Cement Type on Unconfined Compressive Strength and Linear Expansion of CementStabilized Phosphogypsum," Journal of Environmental Engineering, Vol. 129, 2003, pp. 956-960. doi:10.1061/(ASCE)0733-9372(2003)129:10(956)

[3] H. Tayibi, M. Choura, F. A. López, F. J. Alguacil and A.
López-Delgado, "Environmental Impact and Management of Phosphogypsum (Review)," Journal of Environmental Management, Vol. 90, 2009, pp. 2377-2386. doi:10.1016/i.jenvman.2009.03.007

[4] J. P. Bolivar, R. Garcia-Tenorio and F. Vaca, "Radioecological Study of an Estuarine System Located in the South of Spain," Water Research, Vol. 34, 2000, pp. 2941-2950. doi:10.1016/S0043-1354(99)00370-X

[5] P. M. Rutherford, M. J. Dudas and R. A. Samek, "Environmental Impacts of Phosphogypsum," Science of the Total Environment, Vol. 149, No. 1-2, 1994, pp. 1-38. doi:10.1016/0048-9697(94)90002-7

[6] United States Environmental Protection Agency (USEPA), "National Emission Standards for Hazardous Air Pollutants," Subpart R, 2002.

[7] "Federal Register," 40 CFR Part 61, Subpart 61, Vol. 64, No. 2, 3 February 1999, pp. 5573-5580.

[8] USEPA, "Code of Federal Regulations," Title 40, Vol. 7, Parts 61.202 and 61.204 (40CFR61.202 and 40CFR 61.204), 1998

[9] J. L. Mas, E. G. San Miguel, J. P. Bolívar, F. Vaca and J. P. Pérez-Moreno, "An Assay on the Effect of Preliminary Restoration Tasks Applied to a Large TENORM Wastes Disposal in the South-West of Spain," Science of the Total Environment, Vol. 364, 2006, pp. 55-66. doi:10.1016/j.scitotenv.2005.11.006

[10] R. Brina and A. G. Miller, "Direct Detection of Trace Levels of Uranium by LÁSER-Induced Kinetic Phosphorimetry," Analytical Chemistry, Vol. 64, 1992, pp. 1413-1418. doi:10.1021/ac00037a020

[11] “Uranium Radiation Properties," WISE Uranium Project, 2006. http://www.wise-uranium.org/rup.html.

[12] H. Tayibi, C. Gascó, N. Navarro, A. López-Delgado, M. Choura, F. J. Alguacil and F. A. López, 5 ème Edition, Journées Internationales des Géosciences de l'Environnement, Fès (Morocco), 2009.

[13] W. W. Flynn, "The Determination of Low Level of Polonium-210 in Environmental Materials," Analytica Chimica Acta, Vol. 43, 1968, pp. 221-227. doi:10.1016/S0003-2670(00)89210-7

[14] H. Tayibi, C. Pérez, F. A., López, M. Choura and A. López-Delgado, "International Congress of Solid Waste Management \& Sustainable Development," Hammamet, Tunisia, 2008. 
[15] B. R. Miloš and V. T. Dragan, "Phosphogypsum Surface Characterisation Using Scanning Electron Microscopy," Acta Periodica Technologica, Vol. 34, 2003, pp. 61-70.

[16] W. C. Burnett, M. K. Schultz and D. H. Carter, "Radionuclide Flow during the Conversion of Phosphogypsum to Ammonium Sulphate," Journal of Environmental Radioactivity, Vol. 32, No. 1-2, 1996, pp. 33-51. doi:10.1016/0265-931X(95)00078-O

[17] E. M. El-Afifi, M. A. Hilal, M. F. Attallah and S. A. ElReefy, "Characterization of Phosphogypse Wastes Associated Wit Phosphoric Acid and Fertilizers Production," Journal of Environmental Radioactivity, Vol. 100, 2009, pp. 407-412. doi:10.1016/j.jenvrad.2009.01.005

[18] "UNSCEAR: United Nations Scientific Committee on the Effect of Atomic, Radiation: Sources and Effects of Ion- izing Radiation," United Nations, New York, 1993.

[19] C. Dueñas, E. Liger, S. Cañete, M. Pérez and J. P. Bolívar, "Exhalation of ${ }^{222} \mathrm{Rn}$ from Phosphogypsum Piles Located at the Southwest of Spain," Journal of Environmental Radioactivity, Vol. 95, 2007, pp. 63-74. doi:10.1016/j.jenvrad.2007.01.012

[20] J. P. Bolívar, J. E. Martín, R. García-Tenorio, J. P. PérezMoreno and J. L. Mas, "Behaviour and Fluxes of Natural Radionuclides in the Production Process of a Phosphoric Acid Plant," Applied Radiation and Isotopes, Vol. 67, 2009, pp. 345-356. doi:10.1016/j.apradiso.2008.10.012

[21] EC, "Radiological Protection Principals Concerning the Natural Radioactivity of Building Materials," Radiation Protection Report RP-112, EC, European Commission, Luxembourg, 1999. 